\title{
Angiotensin-Converting Enzyme Receptor Genotype and its Activity Level as Potential Predictors of the Severity COVID-19 among Iraqi Patients
}

\author{
Suzan Haleem Kamel ${ }^{1}$, Fadhil Jawad Al-Tu'ma ${ }^{* *}$, Riyadh Mohi Al-Saegh²
}

Department of Chemistry and Biochemistry, College of Medicine, University of Kerbala, Kerbala, Iraq.

2Section of Nephrology, Department of Internal Medicine, College of Medicine, University of Kerbala, Kerbala, Iraq.

*Correspondence to: Fadhil Jawad Al-Tu'ma (E-mail: fadhil.jawad@uokerbala.edu.iq)

(Submitted:09 September 2021 - Revised version received: 16 September 2021 - Accepted: 12 October 2021 - Published online: 26 December 2021)

\begin{abstract}
Objectives: The purpose of this study is to determine whether the angiotensin-converting enzyme activity and various biomarkers are used to investigate the severity of Covid-19 and to study the genetic variation occurs in angiotensin-converting enzyme-2 (ACE-2) receptor in severe Covid-19-related genes in the Iraqi population of Kerbala Province.

Methods: This case-control study was conducted on 176 subjects who survived hospitalization and diagnosed by physician. Various biomarkers including ferritin, C-reactive protein, lactate dehydrogenase, alanine aminotransferase, aspartate aminotransferase, angiotensinconverting enzyme-2 activity levels were determined. Accordingly, they were divided into three groups: 59 of them were infected with severe Covid-19, 54 of them were infected with moderate Covid-19 and 63 of them were checked and obtained as apparently healthy control. Severe and moderate patients were collected from Al-Hayat tertiary center at Al-Hussein Medical City, Kerbala Health Directorates, Kerbala - Iraq during Oct., 2020-July, 2021 with matched age ranged between (23-88) years. Blood samples of apparently healthy and Covid-19 samples were subjected to genomic DNA extraction within 24-48 hours of aspiration. The genomic DNA extracted was subjected to electrophoresis through $1.5 \%$ of agarose gels which was detected by staining with the fluorescent dye ethidium bromide and then visualized by illumination with UV light to confirm the presence and integrity of the extracted DNA

Results: Genotyping of ACE-2 (I/D) polymorphism (rs4646994), which has a high prevalence, was performed by polymerase chain reaction assay. The amplification of an Alu repetitive element in an intron of the ACE-2 has shown three potential genotypes of I/I and D/D as homozygous, and I/D as heterozygous. Individuals with normal homozygous (DD) revealed band of (190 bp), while individuals with normal (II) revealed band of (490 bp), and the individuals with heterozygous (ID) revealed two bands (190, $490 \mathrm{bp}$ ) respectively. Every severe Covid-19 group carried (DD) allele genotype, moderate group carried (ID and II) alleles and finally the control group carried (DD, ID, II) alleles genotype. Conclusion: In the ACE-2 polymorphism, the D/D genotype allele is implicated as a risk factor for severe Covid-19 patients, in Iraqi population. Keywords: COVID-19, homozygote, ferritins, genotype
\end{abstract}

\section{Introduction}

More than 140 million cases of infection with Severe acute respiratory syndrome coronavirus 2 (SARS-CoV-2) have been reported worldwide by April 19, 2021, with over 3 million deaths due to the virus ${ }^{1}$ coronavirus disease situation dashboard. Coronavirus disease 2019 (Covid-19) which emerged in Wuhan, China, has spread to almost all countries and regions of the world, becoming one of the most lethal pandemic after the Spanish flu in 1918-1920. It is caused by an RNA virus (2019 novel coronavirus or $2019-\mathrm{nCoV}$ or SARS-CoV-2). As of July 13, 2020, a total of 12,768,307 confirmed Covid-19 cases and 566,654 related deaths have been reported. Beyond its important morbidity and mortality and the huge burden of health care systems, Covid-19 has a massive societal and economic impact globally. ${ }^{1,2}$ This pathogen was later renamed as severe acute respiratory syndrome coronavirus 2 (SARS-CoV-2) by the coronavirus study group (Gorbalenya, 2020), ${ }^{3}$ and the disease was named coronavirus disease 2019 (Covid-19) by the WHO. Covid-19 can be either silent (asymptomatic) or associated with many symptoms, such as familiar cold symptoms (fever, stuffy nose, cough, weakness) bronchitis and pneumonia. ${ }^{4}$ Covid-19 is moderately infectious with a relatively high mortality rate, but the information available in public reports and published literature is rapidly increasing.

Many risk factors have been described for this coronavirus such as elderly age, male gender, race, obesity, hypertension, diabetes and geographic region. ${ }^{5,6}$
Clinically, most of Covid-19 cases (80\%) are either asymptomatic or have mild forms. ${ }^{7}$ However, about 13.8 and $6.1 \%$ have severe and critical life-threatening disease that requires admission to hospital and sometimes in the intensive care unit. In the context of outstretched heath care systems and limited resources, risk stratification is pivotal to identify patients who the most need in-hospital and intensive management. Biomarkers along with some clinical factors might help to predict adverse outcomes among Covid-19 patients. Hence, we conducted this systematic review and meta-analysis to summarize available data on the association between some common hematological, inflammatory, biochemical parameters and the severity of Covid-19. ${ }^{7,8}$ To date, there is no established curative treatment for Covid-19. Although some drugs such as hydroxychloroquine are integrated in treatment guidelines or under investigation in interventional studies, the management of Covid-19 is mostly supportive. ${ }^{7,9}$ Identifying biological abnormalities induced by Covid-19 may contribute to a better understanding of the pathophysiology of the disease and ultimately guide the development of targeted adjuvant therapies besides antivirals drugs. Furthermore, such information on the biological profile of Covid-19 can guide clinicians in the assessment and treatment of these patients. ${ }^{10}$ Genetic factors also play a major role in Covid19 infection. Inter-individual inherited differences in susceptibility to SARS-CoV-2 infection is linked to the presence of genetic polymorphisms (variants) in many 
genes especially in those that code for the host receptors involved in viral entry process. These DNA changes are transmissible from one generation to another, detectable in at least $1 \%$ of individuals in a population and could explain the differences between individuals in the susceptibility to some multigenic, complex diseases like Covid19. ${ }^{11,12}$ Two main approaches can be used in genetic epidemiology to establish a link between genetic variations and the risk of developing a disease: Genetic linkage analysis and association studies (candidate gene and genome-wide association studies). ${ }^{13}$ Angiotensin-converting enzyme (chromosome Xp22.2) is the enzyme responsible for converting angiotensin-2 to angiotensin (1-7) form, ${ }^{14}$ it is expressed in most organs such as, thyroid and lungs, heart, esophagus, kidney, adipose tissue, liver, retina, the vascular system, the small intestine, nasal and bronchial tissue, and alveolar type II epithelial cells. ${ }^{15,16}$ ACE-2 is also known as a host cell receptor that contributes to the viral infection by corona viruses. The COVID-19 virus binds to the target cells through ACE-2 receptor which makes the COVID-19 attachment, invasion and penetration processes easier. ${ }^{17}$ There are other receptors that can be used but, the virus has greater affinity for ACE-2 and weaker affinities for two other receptors, CD147 and Grp78 (Glucose-Regulate Protein 78). ${ }^{16}$ The ACE-2 expression level has been reported to be significantly increased among men than women, which could explain the male predominance of COVID-19. ${ }^{18,19}$ However, in another study ACE-2 expression was not significantly associated with gender/disease severity bias among Covid-19 Italian patients. ${ }^{20}$ Similar results were obtained by another author, who didn't observe a disparity between age groups and gender groups (male $v s$ female) in ACE-2 gene expression. ${ }^{21}$ ACE-2 is very polymorphic gene with about 1700 polymorphisms and their frequencies vary between populations, some of these polymorphisms were correlated with increased expression of ACE- 2 protein and were more frequent among the East-Asian populations. ${ }^{17,22,23}$ Not only that, ACE deletion allele that is linked to alterations of ACE expression, also influences the spread of the virus and outcomes of infection with COVID-19 especially in the Asian populations. ${ }^{24,25}$ Angiotensin converting enzyme-2 receptor (ACE-2) is a protein on the surface of many cell types. It is an enzyme that generates small proteins - by cutting up the larger protein angiotensinogen - that then go on to regulate functions in the cell. Using the spike-like protein on its surface, the SARS-CoV-2 virus binds to ACE-2 - like a key being inserted into a lock - prior to entry and infection of cells. Hence, ACE-2 acts as a cellular doorway - a receptor - for the virus that causes Covid-19. ACE-2 acts as the receptor for the SARS-CoV-2 virus and allows it to infect the cell. ACE-2 receptor is present in many cell types and tissues including the lungs, heart, blood vessels, kidneys, liver and gastro-intestinal tract. It is present in epithelial cells, which line certain tissues and create protective barriers. The purpose of the presented study is to investigate the activity levels of angiotensin-converting enzyme and various biomarker levels in adults infected with Covid-19 and study the molecular basis of angiotensin-converting enzyme- 2 (ACE-2) receptor in Covid-19-related gene polymorphism in Iraqi populations of Kerbala Province.

\section{Materials and Methods}

The current case-control study was conducted on 176 subjects who survived hospitalization and diagnosed by physician.
Various biomarkers including ferritin, C-reactive protein, lactate dehydrogenase (LDH), alanine aminotransferase (ALT), aspartate aminotransferase (AST), angiotensin-converting enzyme-2 (ACE-2) activity were determined. Accordingly, they were divided into three groups: 59 of them were infected with severe Covid-19, 54 of them were infected with moderate Covid-19 and 63 of them were checked and obtained as apparently healthy control. Severe and moderate patients were collected from Al-Hayat tertiary center at Al-Hussein Medical City, Kerbala Health Directorates, Kerbala-Iraq during Oct., 2020-July, 2021 with matched age ranged between (23-88) years. Blood samples of apparently healthy and Covid-19 samples were obtained from each case and used for some biomarkers determination (ferritin, ALT, AST and ALP activity levels) and molecular studies. One $\mathrm{ml}$ of whole blood was collected in EDTA containing tube and subjected for genomic DNA extraction within 24-48 hours of aspiration. Then DNA concentration and purity were measured by UV absorption at 260 and $280 \mathrm{~nm}$ (Bio Drop, U.K.).

The genomic DNA extracted was subjected to electrophoresis through $1.5 \%$ of agarose gels electrophoresis in $1 \mathrm{X}$ (TBE) buffer at 100 volts for 75 minutes or until dye markers have migrated an appropriate distance, depending on the size of the DNA to be visualized. The percentage of agarose used depends on the size of fragments to be resolved, where an agarose gels percentage are normally in the range of $0.5 \%$ to $2 \%$; the ethidum bromide staining was done according to Robinson and Lafleche method. ${ }^{26}$ DNA ladder $100 \mathrm{bp}$ bands were used as standard for comparison with bands that resulted for allelic gene migration through gel electrophoresis and then detected at staining with the fluorescent dye ethidium bromide and then visualized by illumination with UV light to confirm the presence and integrity of the extracted DNA.

Genotyping for ACE-2 receptor gene polymorphism was performed by the polymerase chain reaction- Amplification Refractory Mutation System (PCR-ARMS) method using thermocycler (Biometra, Germany). The primers were taken in a lyophilized state; their units are known as a mass in picomoles then mixed by suitable vortex and their sequence of ACE-2 receptor gene was listed in Table 1.

The subsequent steps were done for the reconstitution and dilution of the primers: The tube was centrifuged at 10,000 rpm for 5-10 min before de-capping. The chosen volumes from nuclease free water were added according to the manufacturer to obtain a $100 \mathrm{P}$-moles/ $\mu \mathrm{l}$ (master stock). Ten microliters of the master stock were transported to a $0.5 \mathrm{ml}$ eppendorf tube that contained $90 \mu \mathrm{l}$ of nuclease free water to obtain a 10 pmoles/ $\mu \mathrm{l}$ a working primer stock solution. The master stock and working stock were kept at $-20^{\circ} \mathrm{C}$. The working stock was warmed up and kept on ice for use in PCR and then stored at $-20^{\circ} \mathrm{C}$ after each use.

Table 1. Primers used in molecular study of angiotensinconverting enzyme receptor-2 gene polymorphism

\begin{tabular}{llcc}
\hline Primer name & Sequence & $\begin{array}{c}\text { Annealing } \\
\text { temp. }\left({ }^{\circ} \mathbf{C}\right)\end{array}$ & $\begin{array}{c}\text { Product } \\
\text { size (bp) }\end{array}$ \\
\hline ACE-rs4646994-F & $\begin{array}{l}5^{\prime}-\text { CTGGAGACCA }^{\prime} \\
\text { CTCCCATCCTTTCT-3 }\end{array}$ & 58 & 190 \\
ACE-rs4646994-R & $\begin{array}{l}5^{\prime} \text {-GATGTGGCCATCA } \\
\text { CATTCGTCAGAT-3 }\end{array}$ & 58 & 490 \\
\hline
\end{tabular}


The reaction setup and thermal cycling protocol of the PCR components and program for ACE-2 receptor gene show in Table 2.

Electrophoresis involves running a current through a gel loaded with the molecules of interest. The movement of the samples is directed based on the charge that the molecule carries. Based on the size and charge, the molecules will travel through the gel at different speeds, allowing them to be separated from one another as shown in Figure 1. Since, all the DNA molecules possess same amount of charge per mass, the gel electrophoresis separates them on the basis of size only.

Body mass index (BMI) was used to define obesity. The range of BMI $\left(18.5-24.99 \mathrm{~kg} / \mathrm{m}^{2}\right)$ that set it WHO but it does

\begin{tabular}{|c|c|c|c|}
\hline Steps & Temp., ${ }^{\circ} \mathrm{C}$ & Time & Cycle \\
\hline Initial denaturation & 95 & $5 \mathrm{~min}$. & 1 \\
\hline Denaturation & 95 & $30 \mathrm{sec}$. & 30 \\
\hline Annealing & 58 & $30 \mathrm{sec}$. & \\
\hline Extension & 72 & $30 \mathrm{sec}$. & \\
\hline Final extension & 72 & $5 \mathrm{~min}$ & 1 \\
\hline
\end{tabular}

not accurately indicate the degree of fatness. The body mass index was measure by dividing weight in kilograms by length of individual in square meter.

\section{Results}

Main features of 176 individuals included in this study were divided into 63 cases as apparently health control and the other 113 cases of them were infected with Covid-19 as summarized in Table 3. The Covid-19 patients were sub-divided into two groups depending on the severity of the disease and some biomarker levels changes. Mild Covid-19 includes 54 patients and the remaining 59 patients were infected with severe Covid-19 and its complications. The mean \pm SD of age and BMI of each groups were indicated in Table 3.

In this table a significant differences between each of severe and moderate Covid-19 group as compared with control group was observed with respect to the age $(P<0.001)$, while BMI data show a non-significant results $(P=0.817$ and $P=0.495)$ respectively. The mean \pm SD values of angiotensinconverting enzyme-2 (ACE-2) activity levels was higher in the severe and moderate Covid-19 as compared with that found in healthy control $(4.74 \pm 0.85,3.83 \pm 0.82$, and $3.03 \pm 0.82$ $\mathrm{ng} / \mathrm{ml})$ respectively. A non-significant differences between moderate and control groups $(\boldsymbol{P}=\mathbf{0 . 7 2 1})$ was obtained and

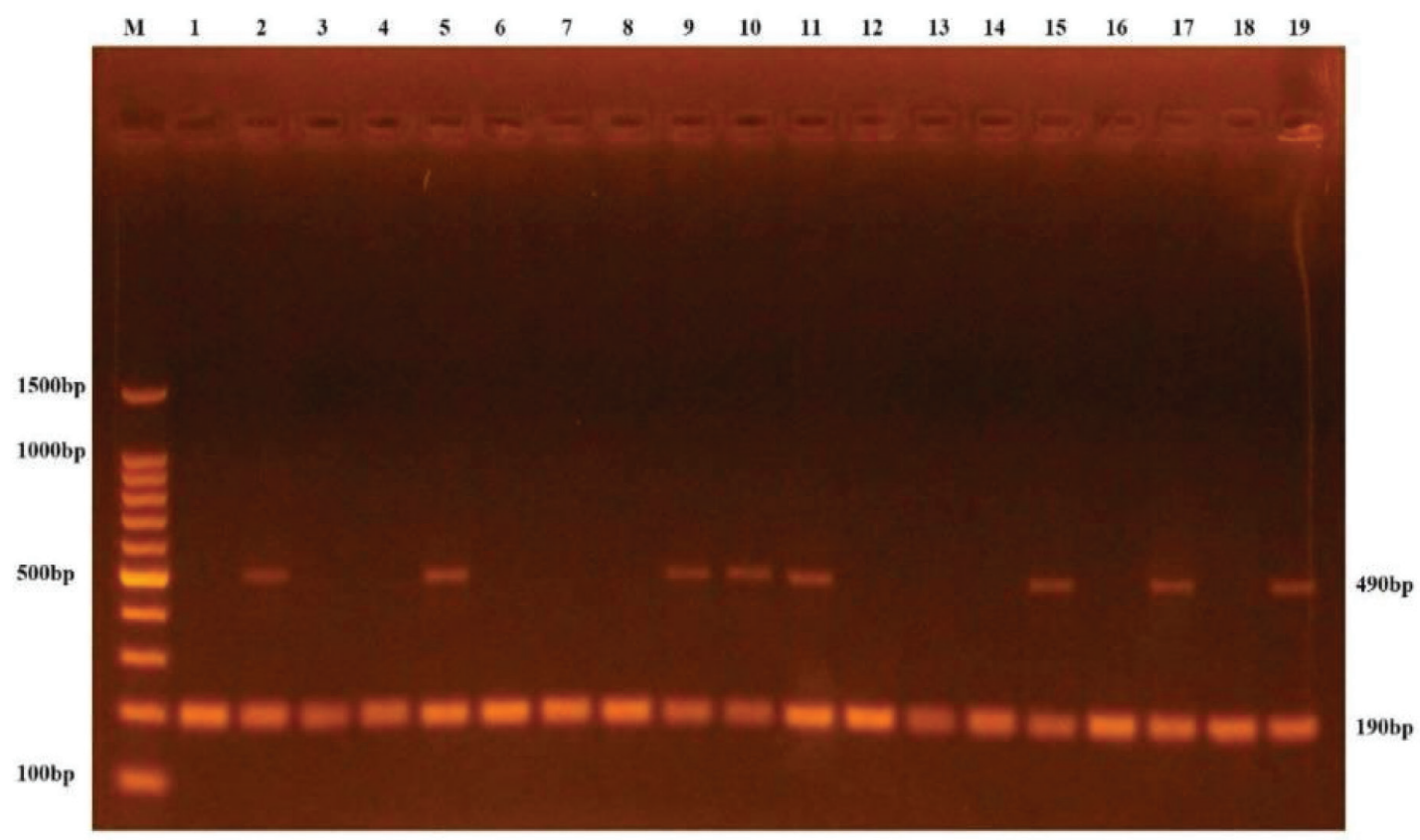

Fig. 1 The amplification of rs 4646994 region of human samples were fractionated on $1.5 \%$ agarose gel electrophoresis stained with ethidium bromoide. M: DNA Marker (Ladder 100 bp). Lanes 1-19 resemble 190, 490 bp of PCR products.

Table 3. Comparison of age and body mass index and angiotensin-converting enzyme between moderate and severe Covid-19 groups as compared with control group

\begin{tabular}{|c|c|c|c|c|c|c|}
\hline Parameters & $\begin{array}{c}\text { Moderate Covid-19 } \\
N=54 \text { Mean } \pm \text { SD }\end{array}$ & $\begin{array}{c}\text { Control group } \\
N=63 \text { Mean } \pm \text { SD }\end{array}$ & $P$-value & $\begin{array}{c}\text { Control group } N=63 \\
\text { Mean } \pm S D\end{array}$ & $\begin{array}{c}\text { Severe Covid-19 } \\
N=59 \text { Mean } \pm \text { SD }\end{array}$ & $P$-value \\
\hline Age, year & $52.06 \pm 14.35$ & $40.03 \pm 11.86$ & $<0.001$ & $40.03 \pm 11.86$ & $59.1 \pm 12.64$ & $<0.001$ \\
\hline $\mathrm{BMI}, \mathrm{kg} / \mathrm{m}^{2}$ & $32.59 \pm 5.52$ & $33.31 \pm 5.83$ & 0.495 & $33.31 \pm 5.83$ & $33.07 \pm 5.72$ & 0.817 \\
\hline ACE-2 activity, ng/ml & $3.83 \pm 0.82$ & $3.03 \pm 0.82$ & 0.721 & $3.03 \pm 0.82$ & $4.74 \pm 0.85$ & 0.001 \\
\hline
\end{tabular}

BMI, Body mass index; N, Number; Significant $P<0.05$; SD, Standard Deviation. 
significant differences between severe Covid-19 and apparently health control group $(\boldsymbol{P}<\mathbf{0 . 0 0 1})$.

The angiotensin-converting enzyme gene (ACE-2) was located on chromosome 17q23.3, spansv21 kb, and comprises 26 exons and 25 introns. Exon 26 encodes for the functionally important membrane-anchoring domain of the ACE- 2 protein.

Insertion (I allele) polymorphism had band in (490 bp) of an Alu repetitive element in an intron of the ACE-2 receptor gene that called homozygotes. Deletion genotype (D allele) had band in (190 bp) that lack the repetitive element also called homozygotes, while (ID) genotype had two band I and $\mathrm{D}$ in the same gene that mean in the same gene had insertion and deletion of an Alu repetitive element in intron of the ACE- 2 receptor gene and it is called heterozygotes, so the two band in the same location differ in speed of migration as shown in Figure 1. The (DD) genotype showed band at $190 \mathrm{bp}$, (II) genotype showed band at $490 \mathrm{bp}$ while (ID) genotype showed both bands at 190 and $490 \mathrm{bp}$. The size of each of (DD, II and ID) genotypes was determined as indicated in Table 4.

Therefore, individuals with normal homozygous deletion/ deletion (DD) revealed band size of (190 bp), while individuals with normal insertion/insertion (II) revealed band size of (490 bp), and the individuals with heterozygous insertion/ deletion (ID) revealed two bands size at each of (190, $490 \mathrm{bp})$ respectively, Figure 1.

Table 4 shows the comparison of age and body mass index in moderate Covid-19 group with the ACE-2 receptor gene allele types by unpaired $t$ test. In this table show age and BMI are non-significant correlated with moderate Covid-19 group according to the allele (ID) and (II).

Table 5 shows a significant result for mean \pm SD of age between severe Covid-19 as compared with apparently control groups according to the ACE-2 receptor gene polymorphism allele deletion/deletion (DD), but the relation with BMI was non-significant.

Table 6 show the results obtained for the relation between hypertension and T2DM associated with Covid-19 are significant as compared with control groups according to the ACE-2 receptor gene polymorphism allele (DD) but for moderate Covid-19 group the relation was non-significant with ACE-2 receptor gene polymorphism alleles (ID) and (II).

As shown in Table 6 the effect of smoking nicotine on the renin-angiotensin system was observed which indicated that $8.7 \%$ of angiotensin-converting enzyme receptor gene polymorphism allele (ID) in moderate Covid-19 and $8.5 \%$ of (DD) allele in severe Covid-19 infection were smokers respectively as compared with control group. Nicotine can impact the angiotensin-converting enzyme (ACE-2), which is relevant because coronaviruses bind to ACE-2. Current and past tobacco smoking is associated with changes in ACE-2 receptor expression. Table 6 indicated that most of patients whether it is severe or moderate infection with Covid-19 nonsmokers, the reason is due to nicotine may bind with the ACE- 2 receptor and decrease levels of ACE-2 in multiple organs. ${ }^{27}$ Smoking is associated with increased susceptibility and mortality in MERS-CoV infection, potentially due to up-regulation of dipeptidyl peptidase-IV, the host receptor for MERS-CoV, in smokers. In the context of respiratory viruses, smoking has been reported to cause increased hospital and ICU admissions with influenza infection, greater severity with respiratory syncytial virus bronchiolitis and increased mortality with viral pneumonia. ${ }^{28}$ In Table 7 all parameters (ferritin, LDH, CRP, ACE2, ALT and AST) are significantly elevated in moderate group according to the allele ID compared with control group expect ALP, while they are significantly elevated in severe Covid-19 group as compared with control according to the DD allele expect ACE-2 which was non-significantly changes.

\begin{tabular}{|c|c|c|c|}
\hline \multirow[b]{2}{*}{ Parameters } & \multicolumn{2}{|c|}{ Moderate Covid-19, $N=54$} & \multirow[b]{2}{*}{$P$-value } \\
\hline & $\begin{array}{c}\text { ID allele } N=46 \\
\text { Mean } \pm \text { SD }\end{array}$ & $\begin{array}{c}\text { Il allele } N=8 \\
\text { Mean } \pm \text { SD }\end{array}$ & \\
\hline Age, Year & $52.91 \pm 14.62$ & $47.13 \pm 12.32$ & 0.297 \\
\hline $\mathrm{BMI},\left(\mathrm{kg} / \mathrm{m}^{2}\right)$ & $33.07 \pm 5.6$ & $29.83 \pm 4.38$ & 0.126 \\
\hline
\end{tabular}

N, Number; BMI, Body Mass Index; SD, Standard Deviation; $P$-value, Prober value; ID, Insertion/Deletion; II, Insertion/Insertion.

Table 5. Shows a comparison between severe Covid-19 and control groups according to the type of ACE-2 receptor gene allele deletion/deletion for age and BMI

\begin{tabular}{|c|c|c|c|}
\hline Parameters & $\begin{array}{l}\text { Severe Covid-19 DD allele } \\
\qquad N=59 \text { Mean } \pm \text { SD }\end{array}$ & $\begin{array}{c}\text { Control DD allele } \\
N=27 \text { Mean } \pm \text { SD }\end{array}$ & $P$-value \\
\hline Age, Year & $59.1 \pm 12.64$ & $41.96 \pm 12.62$ & $<0.001$ \\
\hline $\mathrm{BMI},\left(\mathrm{kg} / \mathrm{m}^{2}\right)$ & $33.07 \pm 5.72$ & $33.93 \pm 6.41$ & 0.537 \\
\hline
\end{tabular}

N, Number; BMI, Body Mass Index; SD, Standard Deviation; P-value, Prober value; DD, Deletion/Deletion allele found in sever Covid-19 and control group.

Table 6. Comparison of gene polymorphism of ACE-2 alleles (ID and II) with hypertension, type 2 diabetes mellitus and smoking in moderate Covid-19 cases and compared with severe and control alleles (DD)

\begin{tabular}{|c|c|c|c|c|c|c|c|}
\hline \multirow[b]{2}{*}{ Parameters } & & \multicolumn{2}{|c|}{ Moderate Covid-19 } & \multirow[b]{2}{*}{$P$-value } & \multirow{2}{*}{$\begin{array}{c}\text { Severe Covid-19 } \\
\text { DD allele } \\
N=59(\%)\end{array}$} & \multirow{2}{*}{$\begin{array}{c}\text { Control } \\
\text { DD allele } \\
N=27(\%)\end{array}$} & \multirow[b]{2}{*}{$P$-value } \\
\hline & & $\begin{array}{c}\text { ID allele } \\
N=46(\%)\end{array}$ & $\begin{array}{c}\text { II allele } \\
N=8(\%)\end{array}$ & & & & \\
\hline \multirow[t]{2}{*}{ Hypertension } & with & 25 (54.3\%) & $5(62.5 \%)$ & \multirow{2}{*}{0.720} & $26(44.1 \%)$ & $0(0.0)$ & \multirow[t]{2}{*}{$<0.001$} \\
\hline & without & 21 (45.7\%) & $3(37.5 \%)$ & & 33 (55.9\%) & 27 (100\%) & \\
\hline \multirow[t]{2}{*}{ T2DM } & with & $16(34.8 \%)$ & $4(50.0 \%)$ & \multirow{2}{*}{0.450} & $28(47.5 \%)$ & $0(0.0)$ & \multirow{2}{*}{$<0.001$} \\
\hline & without & 30 (65.2\%) & $4(50.0 \%)$ & & 31 (52.5\%) & $27(100 \%)$ & \\
\hline \multirow[t]{2}{*}{ Smoking } & Yes & $4(8.7 \%)$ & $0(0.0)$ & \multirow{2}{*}{1.000} & $5(8.5 \%)$ & $0(0.0)$ & \multirow{2}{*}{0.320} \\
\hline & No & $42(91.3 \%)$ & $8(100 \%)$ & & $54(91.5 \%)$ & $27(100 \%)$ & \\
\hline
\end{tabular}

N, Number; T2DM, Type 2 Diabetes Mellitus; ID, Insertion/Deletion; II, Insertion/Insertion; $P$ value, Prober value. 


\begin{tabular}{|c|c|c|c|c|c|c|}
\hline \multirow[t]{2}{*}{ Parameters } & \multicolumn{2}{|c|}{$\begin{array}{l}\text { ID allele in moderate Covid-19 } \\
\text { group as compared with control }\end{array}$} & \multicolumn{3}{|c|}{$\begin{array}{l}\text { DD allele in severe Covid-19 } \\
\text { group as compared with control }\end{array}$} & \multirow[b]{2}{*}{$P$-value } \\
\hline & Group & Mean \pm SD & $P$-value & Group & Mean \pm SD & \\
\hline \multirow{2}{*}{ Ferritin, (ng/ml) } & Moderate & $602.24 \pm 509.41$ & \multirow{2}{*}{$<0.001$} & Severe & $765.04 \pm 359.37$ & \multirow{2}{*}{$<0.001$} \\
\hline & Control & $81.36 \pm 47.31$ & & Control & $70.08 \pm 26.96$ & \\
\hline \multirow{2}{*}{ LDH activity, (U/I) } & Moderate & $395.78 \pm 240.34$ & \multirow{2}{*}{$<0.001$} & Severe & $432.9 \pm 211.86$ & \multirow{2}{*}{$<0.001$} \\
\hline & Control & $132.93 \pm 37.95$ & & Control & $140.98 \pm 39.41$ & \\
\hline \multirow{2}{*}{ CRP, (mg/dl) } & Moderate & $9.56 \pm 3.26$ & \multirow{2}{*}{$<0.001$} & Severe & $15.02 \pm 23.53$ & \multirow{2}{*}{$<0.001$} \\
\hline & Control & $0.34 \pm 0.15$ & & Control & $0.36 \pm 0.13$ & \\
\hline \multirow{2}{*}{ ACE-2 activity, (ng/ml) } & Moderate & $3.14 \pm 0.83$ & \multirow{2}{*}{0.001} & Severe & $3.74 \pm 0.85$ & \multirow{2}{*}{0.345} \\
\hline & Control & $2.55 \pm 0.62$ & & Control & $3.66 \pm 0.64$ & \\
\hline \multirow{2}{*}{ ALT activity, (U/I) } & Moderate & $60.81 \pm 19.25$ & \multirow{2}{*}{$<0.001$} & Severe & $101.11 \pm 266.69$ & \multirow{2}{*}{$<0.001$} \\
\hline & Control & $29.56 \pm 11.71$ & & Control & $26.54 \pm 9.7$ & \\
\hline \multirow{2}{*}{ AST activity, (U/I) } & Moderate & $41.28 \pm 12.32$ & \multirow{2}{*}{$<0.001$} & Severe & $51.6 \pm 53.43$ & \multirow{2}{*}{$<0.001$} \\
\hline & Control & $22.77 \pm 8.33$ & & Control & $23.54 \pm 8.78$ & \\
\hline \multirow{2}{*}{ ALP activity, (U/I) } & Moderate & $89.87 \pm 30.73$ & \multirow{2}{*}{0.063} & Severe & $109.48 \pm 39.34$ & \multirow{2}{*}{$<0.001$} \\
\hline & Control & $77.12 \pm 23.52$ & & Control & $73.66 \pm 24.41$ & \\
\hline
\end{tabular}

LDH: Lactate dehydrogenase; CRP: C- Reactive protein; ACE-2: Angiotensin Converting Enzyme; ALT: Alanine Aminotransferase; ALP: Alkaline phosphatase; AST: Aspartate Aminotransferase; S.D: Standard Deviation; DD: Deletion/Deletion; ID: Insertion/Deletion.

Table 8 show the comparison of biochemical in control group according to allele. In this table all parameters in control group are non-significant according to the allele DD and ID expect ACE-2 is significant.

\section{Discussion}

As indicated previously, age and BMI are non-significantly in moderate Covid-19 group according to the (ID) and (II) allele as shown in Table 2, whereas age is significant between severe and control groups according to the deletion/deletion allele (DD), as shown in Table 3 but BMI was non-significantly. The DD allele found in severe and control group but was absent in moderate group.

The ACE-2 receptor gene polymorphism allele (DD) in severe Covid-19 was significantly associated with hypertension and T2DM as compared with control groups $\boldsymbol{P}<\mathbf{0 . 0 0 1}$, but the (ID) and (II) alleles in moderate Covid-19 group was association non-significantly, $P=0.720$ and $P=0.450$ respectively as shown in Table 4 . The total 113 cases of Covid-19 patients were selected with demographic and clinical characteristics. We observed that high frequency of hypertensive patients was (54.3\%) as compared to diabetic (34.8\%) as shown in Table 4. In contrast, de Abajo et al., found higher prevalence of diabetes in 1339 Covid-19 cases as compared with 13,390 matched controls $(27.2 \%$ vs $20.3 \%$; crude odds ratio, OR, 1.50). ${ }^{29}$ Similarity, Singh et al., pooled different studies $(N=2209)$ and found higher percentage of hypertension (21\%) as compared to diabetes $(11 \%)$ and CVD (7\%). ${ }^{30}$ In contrast, a meta-analysis of Covid-19 patients ( $N=1576$ patients) reported percentage of different comorbid conditions such as hypertension $(17 \%)>$ diabetes $(8 \%))^{31}$ To date, few studies have been published that investigate the relationship between ACE-2 gene polymorphism and Covid-19 severity, but we are

\begin{tabular}{lccc}
$\begin{array}{l}\text { Table 8. Comparison of biochemical in control group according } \\
\text { to allele }\end{array}$ & Group & Mean \pm SD & P-value \\
\hline Parameters & DD allele & $70.08 \pm 26.96$ & 0.581 \\
\hline Ferritin, (ng/ml) & ID allele & $81.36 \pm 47.31$ & \\
& DD allele & $140.98 \pm 39.41$ & 0.441 \\
LDH activity, (U/l) & ID allele & $132.93 \pm 37.95$ & \\
& DD allele & $0.36 \pm 0.13$ & 0.278 \\
CRP, (mg/dl) & ID allele & $0.34 \pm 0.15$ & \\
& DD allele & $3.66 \pm 0.64$ & $<0.001$ \\
ACE-2 activity, (ng/ml) & ID allele & $2.55 \pm 0.62$ & \\
& DD allele & $26.54 \pm 9.7$ & 0.305 \\
ALT activity, (U/l) & ID allele & $29.56 \pm 11.71$ & \\
& DD allele & $23.54 \pm 8.78$ & 0.994 \\
AST activity, (U/l) & ID allele & $22.77 \pm 8.33$ & \\
& DD allele & $73.66 \pm 24.41$ & 0.420 \\
ALP activity, (U/l) & ID allele & $77.12 \pm 23.52$ &
\end{tabular}

LDH, Lactate dehydrogenase; CRP, C- Reactive protein; ACE-2, Angiotensin Converting Enzyme-2; ALT, Alanine aminotransferase; ALP,

Alkaline phosphatase; AST, Aspartate aminotransferase; SD, Standard Deviation; DD, Deletion/Deletion; ID, Insertion/Deletion.

still lacking definite results. ${ }^{17,32-34}$ In present study, we observed that individual with 'DD' genotype showed significantly 3.69fold higher risk of Covid-19 severity. Similarly, other studies found that ACE-1 D/D-genotype showed association with Covid-19 related mortality. ${ }^{35,36}$ Gomez et al. found D allele was significantly associated with hypoxemic as compared to non-hypoxemic patients; however, 'DD' genotype individuals did not show any association with Covid-19 infection. ${ }^{37}$ 
Some studies have reported an association of the DD genotype of ACE-2 polymorphism and higher circulating levels and activity of ACE- $2,{ }^{38}$ which could explain the higher susceptibility to develop severe forms of the disease in patients with the DD genotype, in addition to hypertension and T2DM. SARS-CoV-2 sequesters ACE-2 to invade cells, decreasing the bioavailability of ACE-2 which entails a reduction in the degradation of ANG II and an exacerbation of the damaging effects of ANG II. ${ }^{39}$ Thus, the lung injury and inflammation caused by the reduced ACE-2 levels due to the viral infection, and also by the hypertension and diabetes may be worsened by ACE-2 genotypes that further increase ACE-2 levels, and hence ANG II levels, such as the DD genotype of ACE-2 analyzed. In our study we confirmed that ACE-2 levels are associated with the DD genotype of both polymorphisms, which in turn is associated with greater severity of the disease in hypertensive and T2DM. Although according to our data we could not affirm a direct association with Covid-19 severity.

Covid-19 is a highly contagious disease characterized by high mortality, especially for patients with severe comorbidities such as diabetes, hypertension, CVD and CKD. ${ }^{9}$ The documented history of diabetes has been stated to be an independent indicator of morbidity and death in SARS patients. $^{40,41}$ Diabetes hyperglycemia is suspected to cause immune response dysfunction, which fails to regulate the spread of invasive pathogens. Therefore, diabetic individuals are considered to be more prone to infections and incidence of infectious diseases and it will increase associated comorbidities. ${ }^{42}$ A study was released by the Chinese Centre for Disease Control and Prevention, which showed elevated mortality rate in people with diabetes $(2.3 \%$, total and $7.3 \%$, diabetes patients) study was performed in 72,314 cases of Covid-19. ${ }^{43}$

Blood pressure homeostasis maintained by renin-angiotensin system (RAS). ${ }^{44,45}$ RAS system modulated by ACE- 1 and ACE-2, angiotensin I is converted into angiotensin II (ATII) by ACE1 and degraded bioactive bradykinin. ${ }^{46}$ Insertion/deletion (I/D) polymorphism has been correlated with levels of circulating and tissue ACE-1 and influences almost half of the variability of serum ACE levels in the general population. The 'D' allele of ACEI/D is associated with higher ACE activity. ${ }^{47}$ This means individuals with DD genotype showed approximately twice ACE activity levels as compared to II genotype individuals. ${ }^{48}$ The 'D' allele of ACE-1 gene is significantly associated with hypoxemic group as compared to non-hypoxemic group. ${ }^{49}$ Recently, Delanghe et al. found that the prevalence of Covid-19 in 33 countries has been substantially associated with ACE1 I/D polymorphism. ${ }^{50}$

However, our results clearly revealed that polymorphisms of the ACE-2 gene are related to the risk of developing severe Covid-19 (ICU admission) in hypertension and diabetic patients. Our study confirms with previously reported findings of another ACE polymorphism on Covid-19 patients with hypertension ${ }^{37}$ however; it did not corroborate the association with Covid-19 severity found by Gomez et al. and other authors for the ACE I/D polymorphism, regardless of comorbidities. Unlike these studies, we also found an additional association of D Allele with enhanced severity in hypertension and diabetic patients, and interestingly, we further found a higher prevalence of the DD, ID genotypes (all containing the D allele) among deceased ICU-patients, not described so far, confirming the deleterious effect of the D allele in Covid-19 outcomes. Precisely most of these patients were hypertensive.
In Table 7 all parameters (Ferritin, LDH, CRP, ACE-2, ALT and AST) are significant in moderate group according to the allele ID compared with control group expect ALP. All these parameters are significantly elevated in severe group according to the allele DD as compared with control group expect ACE-2, because D allele responsible for activity of ACE-2 and this allele found homogenous at form DD in severe and control group that carry DD genotype, so that non-significant between severe and control according to the allele DD. Genetic polymorphisms in ACE-2 indicate that the ACE I/D polymorphism, have been shown to affect ACE-2 activity levels and confer susceptibility to hypertension type 2 diabetes, ${ }^{38}$ overweight nephropathy and certain cardiovascular and autoimmune diseases. More specifically, the DD genotype of the ACE I/D polymorphism has been associated to higher levels of serum ACE and higher levels of circulating IL-6 in patients with myocardial infarction. In contrast, the II genotype has been associated to lower circulating ACE levels. Since some of these processes have been reported to be involved in the pathogenesis of Covid-19, the DD genotype could predispose to complications of Covid-19 due to higher baseline ACE levels and its consequences. ${ }^{37}$ Indeed, an association of the DD genotype of the ACE I/D polymorphism with severe Covid-19 has been reported in hypertensive males. ${ }^{37}$ However, analyzing the I/D polymorphism is laborious and time-consuming and some authors have described a preferential amplification of the $\mathrm{D}$ allele. The ACE-2 gene polymorphisms are in complete linkage disequilibrium with the ACE I/D polymorphism, therefore they could be better prognostic markers.

Table 8 show all parameter are non-significant correlated because there were healthy peoples. ACE-2 was significantly to $\mathrm{DD}$ and ID alleles because the D allele is associated with higher ACE-2 activity. Mean ACE activity levels in DD carriers were approximately twice that in II genotype individuals. Therefore, it may be propose a hypothesis that ACE- 2 gene polymorphism may play an important role in patients with Covid-19 who are susceptible to develop severe lung injury or ARDS. $^{48}$

\section{Conclusions}

The severity of Covid-19 patients may depend on age, diabetes, hypertension and ACE-2 gene polymorphism. The observed results suggest that a prospective paradigm of DD genotype that has the potential help to explain the susceptibility of the host response to SARS-Cov-2 infection and involve in numerous pathological. Thus, ACE-2 I/D polymorphism may be act as a useful tool to predict the development of disease and may have an influence on the treatment outcomes against the Covid -19 to establish a population-based therapeutic development.

\section{Acknowledgments}

All authors would like to thank the participated patients and the team of Covid-19 Centers for their support during this study.

\section{Conflicts of Interest}

None. 


\section{References}

1. World Health Organization. (2020). Global surveillance for COVID-19 disease caused by human infection with novel coronavirus (COVID-19): interim guidance, 27 February 2020. World Health Organization

2. Hui, D. S., Azhar, E. I., Madani, T. A., Ntoumi, F., Kock, R., Dar, O., et al. (2020). The continuing 2019-nCoV epidemic threat of novel coronaviruses to global health-The latest 2019 novel coronavirus outbreak in Wuhan, China. International Journal of Infectious Diseases, 91: 264-266.

3. Calisher C, Carroll D, Colwell R, Corley RB, Daszak P, Drosten C, et al. (2020). Statement in support of the scientists, public health professionals, and medical professionals of China combatting COVID-19. The Lancet, 395(10226), e42-e43.

4. Singhal, T. (2020). A review of coronavirus disease-2019 (COVID-1de Abajo, F. J., Rodríguez-Martín, S., Lerma, V., Mejía-Abril, G., Aguilar, M., García-Luque, A., and Elvira, C. (2020). Use of renin-angiotensin-aldosterone system inhibitors and risk of COVID-19 requiring admission to hospital: a casepopulation study. The Lancet, 395(10238), 1705-1714.9). The Indian Journal of Pediatrics, 87(4): 281-286.

5. Richardson, S., Hirsch, J. S., Narasimhan, M., Crawford, J. M., McGinn, T., Davidson, K. W., ... \& Northwell COVID-19 Research Consortium. (2020). Presenting characteristics, comorbidities, and outcomes among 5700 patients hospitalized with COVID-19 in the New York City area. JAMA, 323(20): 2052-2059.

6. Scully E.P., Haverfield J., Ursin R.L., Tannenbaum C., Klein S.L. Considering how biological sex impacts immune responses and COVID-19 outcomes. Nat Rev Immunol. 2020;20(7):442-447.

7. Gandhi, M., Yokoe, D. S., \& Havlir, D. V. (2020). Asymptomatic transmission, the Achilles' heel of current strategies to control Covid-19. N Engl J Med 2020; 2160-382:2158.

8. Lu, R., Zhao, X., Li, J., Niu, P., Yang, B., Wu, H., et al. (2020). Genomic characterisation and epidemiology of 2019 novel coronavirus: implications for virus origins and receptor binding. The Lancet, 395(10224): 565-574.

9. Zhou, F., Yu, T., Du, R., Fan, G., Liu, Y., Liu, Z., et al. (2020). Clinical course and risk factors for mortality of adult inpatients with COVID-19 in Wuhan, China: a retrospective cohort study. The Lancet, 395(10229): 1054-1062.

10. Strafella, C., Caputo, V., Termine, A., Barati, S., Caltagirone, C., Giardina, E., \& Cascella, R. (2020). Investigation of genetic variations of IL6 and IL6r as potential prognostic and pharmacogenetics biomarkers: implications for covid-19 and neuroinflammatory disorders. Life, 10(12), 351

11. Torres M.M., Acosta C.P., Sicard D.M. Susceptibilidad genética y riesgo de cáncer gástrico en una población del Cauca. Biomedica. 2004;24:153-162.

12. Sieńko J., Kotowski M., Bogacz A. COVID-19: the influence of ACE genotype and ACE-I and ARBs on the course of SARS-CoV-2 infection in elderly patients. Clin Interv Aging. 2020;15:1231-1240.

13. Tabor, H. K., Risch, N. J., \& Myers, R. M. (2002). Candidate-gene approaches for studying complex genetic traits: practical considerations. Nature Reviews Genetics, 3(5), 391-397

14. Guo, L., Ren, L., Yang, S., Xiao, M., Chang, D., Yang, F., et al. (2020). Profiling early humoral response to diagnose novel coronavirus disease (COVID-19). Clinical Infectious Diseases, 71(15): 778-785.

15. Gheblawi M., Wang K., Viveiros A. Angiotensin-converting enzyme 2: SARSCoV-2 receptor and regulator of the renin-angiotensin system: celebrating the 20th anniversary of the discovery of ACE2. Circ. Res. 2020;126(10): $1456-1474$.

16. Mariappan V., Balakrishna S.R.R., Pillai A. Angiotensin-converting enzyme 2: a protective factor in regulating disease virulence of SARS-COV-2. IUBMB Life. 2020 Dec;72(12):2533-2545.

17. Delanghe, J., Speeckaert, M., et al. (2020). The host's angiotensin-converting enzyme polymorphism may explain epidemiological findings in COVID-19 infections. Clinica Chimica Acta, 505: 192-193.

18. Zhao Y., Zhao Z., Wang Y., Zhou Y., Ma Y., Zuo W. Single-cell RNA ex-pression profiling of ACE2, the putative receptor of Wuhan 2019-nCov. bioRxiv. 2020.

19. Gagliardi, M. C., Tieri, P., Ortona, E., \& Ruggieri, A. (2020). ACE2 expression and sex disparity in COVID-19. Cell Death Discovery, 6(1): 1-2.

20. Asselta, R., Paraboschi, E. M., Mantovani, A., \& Duga, S. (2020). ACE2 and TMPRSS2 variants and expression as candidates to sex and country differences in COVID-19 severity in Italy. Aging (Albany NY), 12(11): 10087

21. Cai G. Bulk and single-cell transcriptomics identify tobacco-use dis-parity in lung gene expression of ACE2, the receptor of 2019-nCov. medRxiv. 2020.

22. Cao Y., Li L., Feng Z., Wan S., Huang P., Sun X. Comparative genetic analysis of the novel coronavirus (2019-nCoV/SARS-CoV-2) receptor ACE2 in different populations. Cell Discov. 2020;6:11.

23. Chen, N., Zhou, M., Dong, X., Qu, J., Gong, F., Han, Y., et al. (2020). Epidemiological and clinical characteristics of 99 cases of 2019 novel coronavirus pneumonia in Wuhan, China: a descriptive study. The Lancet, 395(10223), 507-513.

24. Sieńko J., Kotowski M., Bogacz A. COVID-19: the influence of ACE genotype and ACE-I and ARBs on the course of SARS-CoV-2 infection in elderly patients. Clin Interv Aging. 2020;15:1231-1240.

25. Pati Abhijit. ACE Deletion Allele Is associated with susceptibility to SARSCoV-2 infection and mortality rate: an epidemiological study in the asian population. Clinica Chimica Acta; International Journal of Clinical Chemistry. 2020:510:455-458.

26. Robinson, D. H., and Lafleche, G. J. (2000). Nucleic acid electrophoresis in agarose gels. Essential Molecular Biology: A Practical Approach, 1: 89-119.

27. Mohamed, T. L., Nguyen, H. T., Abdul-Hafez, A., Dang, V. X., Dang, M. T., Gewolb, I. H., \& Uhal, B. D. (2016). Prior hypoxia prevents downregulation of ACE-2 by hyperoxia in fetal human lung fibroblasts. Experimental Lung Research, 42(3), 121-130.

28. Han, L., Ran, J., Mak, Y. W., Suen, L. K. P., Lee, P. H., Peiris, J. S. M., et al. (2019). Smoking and influenza-associated morbidity and mortality: a systematic review and meta-analysis. Epidemiology, 30(3): 405-417.

29. de Abajo, F. J., Rodríguez-Martín, S., Lerma, V., Mejía-Abril, G., Aguilar, M., García-Luque, A., et al. (2020). Use of renin-angiotensin-aldosterone system inhibitors and risk of COVID-19 requiring admission to hospital: a case-population study. The Lancet, 395(10238): 1705-1714.

30. Singh, A. K., Gupta, R., Ghosh, A., \& Misra, A. (2020). Diabetes in COVID-19: prevalence, pathophysiology, prognosis and practical considerations. Diabetes \& Metabolic Syndrome: Clinical Research \& Reviews, 14(4), 303-310.

31. Yan, Y., Yang, Y., Wang, F., Ren, H., Zhang, S., Shi, X., et al. (2020). Clinical characteristics and outcomes of patients with severe covid-19 with diabetes. BMJ Open Diabetes Research and Care, 8(1), e001343.

32. Dević Pavlić, S., Nadalin, S., Starčević Čizmarević, N., Buretić-Tomljanović, A., Radojčić Badovinac, A., et al. (2020). Could angiotensin-converting enzyme 1 I/D polymorphism be a modificator of COVID-19 response in different populations, diseases, and/or conditions?. Journal of the Renin-Angiotensin-Aldosterone System, 21(3): 1470320320957157.

33. Gemmati, D., Bramanti, B., Serino, M. L., Secchiero, P., Zauli, G., et al. (2020). COVID-19 and individual genetic susceptibility/receptivity: role of ACE1/ ACE2 genes, immunity, inflammation and coagulation. Might the double $\mathrm{X}$-chromosome in females be protective against SARS-CoV-2 compared to the single $X$-chromosome in males?. International Journal of Molecular Sciences, 21(10): 3474

34. Hatami, N., Ahi, S., Sadeghinikoo, A., Foroughian, M., Javdani, F., Kalani, N., et al. (2020). Worldwide ACE (I/D) polymorphism may affect COVID-19 recovery rate: an ecological meta-regression. Endocrine 2020;68: 479-484.

35. Annunziata, S., Bauckneht, M., Albano, D., Argiroffi, G., Calabrò, D., Abenavoli, E.,Young Committee of the Italian Association of Nuclear Medicine (AIMN) et al. (2020). Impact of the COVID-19 pandemic in nuclear medicine departments: preliminary report of the first international survey. European Journal of Nuclear Medicine and Molecular Imaging, 47: 2090-2099.

36. Yamamoto, N., Nishida, N., Yamamoto, R., Gojobori, T., Shimotohno, K., Mizokami, M., \& Ariumi, Y. (2021). Angiotensin-converting enzyme (ACE) 1 gene polymorphism and phenotypic expression of COVID-19 Symptoms. Genes, 12(10), 1572.

37. Gómez, J., Albaiceta, G. M., García-Clemente, M., López-Larrea, C., Amado-Rodríguez, L., Lopez-Alonso, I., ... \& Coto, E. (2020). Angiotensinconverting enzymes (ACE, ACE2) gene variants and COVID-19 outcome. Gene, 762: 145102.

38. Schüler, R., Osterhoff, M. A., Frahnow, T., Seltmann, A. C., Busjahn, A., Kabisch, S., et al. (2017). High-saturated-fat diet increases circulating angiotensin-converting enzyme, which is enhanced by the rs4343 polymorphism defining persons at risk of nutrient-dependent increases of blood pressure. Journal of the American Heart Association, 6(1): e004465.

39. Chang, D., Lin, M., Wei, L., Xie, L., Zhu, G., Cruz, C. S. D. et al. (2020). Epidemiologic and clinical characteristics of novel coronavirus infections involving 13 patients outside Wuhan, China. JAMA, 323(11): 1092-1093.

40. Li, J., Wang, X., Chen, J., Zhang, H., et al. (2020). Association of reninangiotensin system inhibitors with severity or risk of death in patients with hypertension hospitalized for coronavirus disease 2019 (COVID-19) infection in Wuhan, China. JAMA Cardiology, 5(7): 825-830

41. Yang, J. K., Feng, Y., Yuan, M. Y., Yuan, S. Y., Fu, H. J., Wu, B. Y., et al. (2006). Plasma glucose levels and diabetes are independent predictors for mortality and morbidity in patients with SARS. Diabetic Medicine, 23(6), 623-628. 
42. Berbudi, A., Rahmadika, N., Tjahjadi, A. I., et al. (2020). Type 2 diabetes and its impact on the immune system. Current Diabetes Reviews, 16(5): 442.

43. Wu, Z., \& McGoogan, J. M. (2020). Characteristics of and important lessons from the coronavirus disease 2019 (COVID-19) outbreak in China: summary of a report of 72,314 cases from the Chinese Center for Disease Control and Prevention. JAMA, 323(13): 1239-1242.

44. Boehm, M., and Nabel, E. G. (2002). Angiotensin-converting enzyme 2-a new cardiac regulator. New England Journal of Medicine, 347(22): 1795-1797.

45. Skeggs Jr, L. T., Kahn, J. R., et al. (1956). The preparation and function of the hypertensin-converting enzyme. The Journal of Experimental Medicine, 103(3): 295

46. Baudin, B. (2002). New aspects on angiotensin-converting enzyme: from gene to disease, Walter de Gruyter 40 (3), 256-265.
47. Tiret, L., Rigat, B., Visvikis, S., Breda, C., Corvol, P., Cambien, F., et al. (1992). Evidence, from combined segregation and linkage analysis, that a variant of the angiotensin I-converting enzyme (ACE) gene controls plasma ACE levels. American Journal of Human Genetics, 51(1): 197.

48. Rigat, B., Hubert, C., Alhenc-Gelas, F., Cambien, F., Corvol, et al. (1990). An insertion/deletion polymorphism in the angiotensin I-converting enzyme gene accounting for half the variance of serum enzyme levels. The Journal of Clinical Investigation, 86(4): 1343-1346.

49. Itoyama, S., Keicho, N., Quy, T., Phi, N. C., Long, H. T., Van Ban, V., et al. (2004). ACE1 polymorphism and progression of SARS. Biochemical and Biophysical Research Communications, 323(3): 1124-1129.

50. Delanghe, J., Speeckaert, M., \& De Buyzere, M. (2020). The host's angiotensinconverting enzyme polymorphism may explain epidemiological findings in COVID-19 infections. Clinica Chimica Acta, 505, 192-193.

This work is licensed under a Creative Commons Attribution-NonCommercial 3.0 Unported License which allows users to read, copy, distribute and make derivative works for non-commercial purposes from the material, as long as the author of the original work is cited properly. 